\title{
Sugars and alcohol insoluble solids assessment for sweet potato cultivars recommended for Puerto Rico ${ }^{1,2}$
}

\author{
Tania Hernández-Carrión ${ }^{3}$, Carlos E. Ortiz', \\ Rafael Montalvo-Zapata and Luis E. Rivera ${ }^{6}$
}

J. Agric. Univ. P. R. 95(3-4):223-231 (2011)

\begin{abstract}
Sweetness-to-taste and starch content are critical quality attributes for the sweet potato root market in Puerto Rico. Current information in regard to these attributes for the cultivars accepted on Puerto Rico's market is not sufficient for establishing breeding standards and selection programs. The objective was to assess the sugar concentrations and crude starch for cultivars grown in Puerto Rico. From cultivars recommended for Puerto Rico, flours were prepared with raw, boiled and microwaved roots from which glucose, fructose, sucrose and maltose concentrations were determined by using high performance liquid chromatography (HPLC). After the sugar extraction, the insoluble solid fraction of the flour was used to determine the alcohol insoluble solids. Sucrose was the most concentrated sugar in the raw roots. Maltose concentration in boiled and microwaved roots was significantly higher than that in the corresponding raw roots. The alcohol insoluble solids for boiled and microwaved roots were significantly fewer than for raw roots. 'Miguela' should be considered the standard cultivar for sugar and starch content because it stands out with relatively high concentrations of sucrose and fructose, and with a reduced percentage of alcohol insoluble solids.
\end{abstract}

Key words: sweet potato, sugars, alcohol insoluble solids

\section{RESUMEN}

Avalúo de azúcares y sólidos insolubles en alcohol en cultivares de batata recomendados para Puerto Rico

${ }^{1}$ Manuscript submitted to the Editorial Board 29 September 2011.

${ }^{2}$ This work was supported by USDA-CSREES's Special Grant Tropical and Subtropical Agriculture Research. Agreement no. 97-34135-4717.

${ }^{3}$ Former Graduate Student, Department of Agronomy and Soils, University of Puerto Rico-Mayagüez Campus.

${ }^{4}$ Corresponding author. Professor, Department of Crops and Agroenvironmental Sciences, University of Puerto Rico, Mayagüez Campus. Agricultural Experiment Station at Gurabo, P.O. 1306, Gurabo, PR 00778. carlos.ortiz35@upr.edu

${ }^{5}$ Chemist (Ad Honorem), Agricultural Experiment Station. University of Puerto RicoMayagüez Campus.

${ }^{6}$ Agronomist, Department of Crops and Agroenvironmental Sciences. 
El dulce al paladar y el contenido de almidón son atributos críticos para la calidad de la batata en Puerto Rico. La información que existe en cuanto a estos atributos para los cultivares aceptados en Puerto Rico no es suficiente para establecer estándares en los programas de mejoramiento. El objetivo fue realizar un avalúo de la concentración de azúcares y de almidón crudo en cultivares que se usan en Puerto Rico. Usando cultivares recomendados para Puerto Rico, se prepararon harinas de raíces crudas, hervidas y al microondas, a las cuales se les determinaron los azúcares glucosa, fructosa sacarosa y maltosa utilizando cromatografía líquida de alta eficiencia (HPLC, por sus siglas en inglés). Luego de la extracción de azúcares la fracción sólida insoluble de cada harina se usó para determinar los sólidos insolubles en alcohol. Sacarosa fue el azúcar más concentrado en la pulpa cruda. La concentración de maltosa en raíces hervidas y al microondas fue significativamente superior a la obtenida para las raíces crudas. Los porcentajes de sólidos insolubles en alcohol en raíces hervidas y al microondas resultaron significativamente menores que los de raíces crudas. 'Miguela' se puede considerar como el cultivar estándar para azúcares y almidón pues resalta por sus relativamente altas concentraciones de sacarosa y fructosa y por su reducido porcentaje de sólidos insolubles en alcohol.

Palabras clave: batata, camote, azúcares, sólidos insolubles en alcohol

\section{INTRODUCTION}

In Puerto Rico the preference is for sweet potato cultivars combining light yellow-fleshed root, moderate sweetness and relatively high starch content. Sweet potato produced in Puerto Rico is marketed as fresh produce. Consumption is primarily in form of boiled and fried roots and as an ingredient in desserts. For these uses, sweetness-totaste and starch content are critical quality attributes. These attributes must be considered when developing appropriate selection protocols for cultivars adapted to the Puerto Rico market. Current information regarding sugar concentration and starch content of the cultivars accepted by the local market is not sufficient to establish standards for breeding and selection programs.

Starch is the main constituent of the sweet potato flesh. Raw flesh is not considered sweet-to-taste but contains measurable amounts of sucrose, glucose and fructose (Hernández-Carrión et al., 2010; Mcharo and La Bonte, 2007; La Bonte et al., 2000; Lewthwaite et al., 1997). When the raw flesh is heated, its starch is converted primarily to maltose (Walter et al., 1975), whereas the presence of the above mentioned sugars is maintained. Previous research has shown considerable variation in sugar concentrations among sweet potato cultivars (HernándezCarrión et al., 2010; Mcharo and La Bonte, 2007; La Bonte et al., 2000; Lewthwaite et al., 1997; Babu, 1994; Takahata et al., 1992). Substantial variation also exists for starch content among sweet potato cultivars (Aina et al., 2012; Katayama et al., 2006; Noda et al., 1998; Babu, 
1994). Both sugar concentration and starch content appear to be highly influenced by the cropping environment (Noda et al., 1998; Takahata et al., 1992) and by postharvest factors such as length of storage period (Koehler and Kays, 1991; Picha, 1986). These findings indicate the need to evaluate variable environments for a better assessment of sugar concentration and starch content in sweet potato. The objective was to assess sugar concentrations and crude starch (measured as alcohol insoluble solids, AIS) in cultivars commonly grown in Puerto Rico and planted in contrasting seasons to establish basic standards for cultivar evaluation and selection.

\section{MATERIALS AND METHODS}

Four sweet potato cultivars currently recommended for use in Puerto Rico were used in this study: 'Miguela', 'Mina', 'Dominicana' (also known as Canol) and 'Viola'. 'Miguela' and 'Mina' were described as sweet by Badillo-Feliciano et al. (1976). 'Dominicana' is a local landrace considered sweet to taste. 'Viola' is a cultivar released by USDA-ARS and considered moderately sweet to taste when compared to the other cultivars included in this study (University of Puerto Rico, 1997).

Field activities were conducted on the Agricultural Experiment Station farm in the municipality of Juana Díaz. This location has an elevation of $21 \mathrm{~m}$ and is characterized by its semiarid climate and flat landscape. At the site the soil was a Mollisol from the San Antón series (Cumulic Haplustolls). In Puerto Rico, traditional sweet potato cultivars tend to perform better commercially when planted in the mild temperature season (October to January) rather than when planted in the hot season (April to July) (Badillo-Feliciano, 1976). Therefore, we planted during the contrasting seasons: hot (May) and mild (November). During the experiment, average temperature for the hot season was $27.8^{\circ} \mathrm{C}$, whereas in the mild season it was $25.1^{\circ} \mathrm{C}$. In the hot season each cultivar was planted in plots consisting of four beds 0.91 wide by $9.14 \mathrm{~m}$ long. Five replications were used. For the mild season, plot size was seven beds $0.91 \mathrm{~m}$ wide by $10.67 \mathrm{~m}$ long, with four replications. Standard management practices were followed, with water applied by a drip irrigation system. Fertilizer 6-6-12 formulation was used at a rate of $922 \mathrm{~kg} / \mathrm{ha}$. Weeds were controlled by a combination of herbicides and mechanical weeding. Harvest was at 162 days after planting. Roots were cured for two to six days at room conditions.

Cured roots weighing from 150 to $450 \mathrm{~g}$ were selected for sugar and AIS determinations. Selected roots were cleaned, classified in sizes large, medium and small, and uniformly distributed among the processing treatments-raw, boiled or microwaved. After processing, 
the flesh was dried and ground in order to prepare flour following the methodology described by Hernández-Carrión et al. (2010). Sugar was extracted by mixing $20 \mathrm{~g}$ of the above mentioned flour with $100 \mathrm{ml}$ of $80 \%$ ethanol to obtain a filtrate. For the determination of sugars, filtrates were placed in borosilicate chromatography vials, packed in ice, and sent by rapid mail to the University of Louisiana. Glucose, fructose, sucrose and maltose were determined by using the method developed by Picha (1985). This method has been regarded as a reliable HPLC procedure for the quantitative analysis of sugars in sweet potato (Mcharo and La Bonte, 2007). The method uses a chromatograph system coupled to a refractive index detector ${ }^{7}$. Sugar separation was accomplished by using an amino resin chromatographic column ${ }^{8}$ at room temperature. The mobile phase was a 70:30 solution of acetonitrile and HPLC-grade water, with a flow rate of $1.0 \mathrm{ml} / \mathrm{min}$. Sugar concentrations were expressed as percentages of the flour dry weight. Sucrose equivalents were calculated in order to compare cultivars at the same level of sweetness (La Bonte et al., 2000). The formula to calculate sucrose equivalents (SE) was that given by Koehler and Kays (1991), where $\mathrm{SE}=0.74$ (\% glucose $)+1.73(\%$ fructose $)+1.0$ (\% sucrose $)+0.33$ (\% maltose). After the sugar extraction, the insoluble solid fraction of the flour was dried at $55^{\circ} \mathrm{C}$ in a convection oven for $24 \mathrm{~h}$, and then weighed for the AIS determination. For sweet potato, the AIS of the roots reflect their starch content (Walter et al., 1997). In this study AIS were expressed as a percentage of the flour used for the sugar extraction.

Statistical analyses were performed separately for each planting season because the data were unbalanced. In the models, cultivar and storage root processing were considered fixed factors. We used PROC MLXED for the analyses of variance, LSMEANS for means separation, and when needed, Satterthwaite's approximation was used to calculate the degree of freedom for the denominator (Littell et al., 1996; Elliott, 1995).

\section{RESULTS AND DISCUSSION}

Sugars: The interaction of cultivar by processing treatment was significant for all sugars and for the sucrose index in both the hot and mild seasons. In both seasons and for all cultivars, sucrose was the most concentrated sugar in the raw flesh (Table 1). As compared to that

${ }^{7} \mathrm{HLPC}$ equipment was a Beckman Coulter Series 340 chromatograph with a pump model 112, sample injector model 210 and a refractive index detector model 156 . The system used an Integrator model 401 from Varian Instruments.

${ }^{8}$ Column was a Bio-Sil Amino 5 S Resin from Bio Rad Laboratories, CA. 
TABLE 1. Sugar concentrations and sucrose equivalents for sweet potato cultivars planted in two seasons and subjected to three processing treatments.

\begin{tabular}{|c|c|c|c|c|c|c|}
\hline \multirow[b]{2}{*}{ Cultivar } & \multirow{2}{*}{$\begin{array}{c}\text { Type of } \\
\text { processing }\end{array}$} & \multicolumn{4}{|c|}{------------------------- Sugar ----------------- } & \multirow{2}{*}{$\begin{array}{c}\text { Sucrose } \\
\text { equivalents }\end{array}$} \\
\hline & & Glucose & Fructose & Sucrose & Maltose & \\
\hline & & ---------- & ------- Hot & t planting & $\operatorname{season}^{1}-$ & -------------- \\
\hline & & 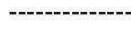 & - & $--\%$ & & $\cdots$ \\
\hline \multirow[t]{2}{*}{ Miguela } & $\begin{array}{l}\text { Raw } \\
\text { Boiled }\end{array}$ & $\begin{array}{l}1.4 \mathrm{a}^{2} \\
0.8 \mathrm{~b}\end{array}$ & $\begin{array}{l}1.9 \mathrm{a} \\
0.9 \mathrm{~b}\end{array}$ & $\begin{array}{l}5.1 \mathrm{a} \\
1.2 \mathrm{de}\end{array}$ & $\begin{array}{l}0.9 \mathrm{~d} \\
7.3 \mathrm{c}\end{array}$ & $\begin{array}{l}10.0 \mathrm{a} \\
5.8 \mathrm{bc}\end{array}$ \\
\hline & Microwaved & $0.7 \mathrm{bc}$ & $0.3 \mathrm{bcd}$ & $2.0 \mathrm{bc}$ & $8.6 \mathrm{c}$ & $6.0 \mathrm{bc}$ \\
\hline \multirow[t]{3}{*}{ Dominicana } & Raw & $0.3 \mathrm{~cd}$ & $0.2 \mathrm{~cd}$ & $2.0 \mathrm{bc}$ & $0.1 \mathrm{~d}$ & $2.8 \mathrm{de}$ \\
\hline & Boiled & $0.5 \mathrm{bcd}$ & $0.3 \mathrm{bcd}$ & $1.4 \mathrm{~cd}$ & $10.8 \mathrm{~b}$ & $6.0 \mathrm{bc}$ \\
\hline & Microwaved & $0.5 \mathrm{bcd}$ & $0.2 \mathrm{~cd}$ & $2.2 \mathrm{~b}$ & $11.9 \mathrm{a}$ & $6.9 \mathrm{~b}$ \\
\hline \multirow[t]{3}{*}{ Viola } & $\begin{array}{l}\text { Raw } \\
\text { Boiled }\end{array}$ & $\begin{array}{l}0.2 \mathrm{~d} \\
0.5 \mathrm{bcd}\end{array}$ & $\begin{array}{l}0.4 \mathrm{bc} \\
0.3 \mathrm{bcd}\end{array}$ & $\begin{array}{l}1.4 \mathrm{~cd} \\
0.8 \mathrm{e}\end{array}$ & $\begin{array}{l}0.4 \mathrm{~d} \\
7.3 \mathrm{c}\end{array}$ & $\begin{array}{l}2.5 \mathrm{e} \\
4.2 \mathrm{~cd}\end{array}$ \\
\hline & Microwaved & $0.5 \mathrm{bcd}$ & $0.4 \mathrm{bc}$ & $2.0 \mathrm{bc}$ & $7.3 \mathrm{c}$ & $5.4 \mathrm{bc}$ \\
\hline & & & ----- Mil & ild plantin & g season & -- \\
\hline \multirow[t]{3}{*}{ Miguela } & Raw & $0.6 \mathrm{a}$ & $0.6 \mathrm{a}$ & $3.7 \mathrm{a}$ & $0.5 f$ & $5.5 \mathrm{~b}$ \\
\hline & Boiled & $0.4 \mathrm{~b}$ & $0.2 \mathrm{e}$ & $0.7 \mathrm{e}$ & $10.0 \mathrm{~b}$ & $4.9 \mathrm{cde}$ \\
\hline & Microwaved & $0.6 \mathrm{a}$ & $0.4 \mathrm{c}$ & $1.3 \mathrm{~d}$ & $11.0 \mathrm{a}$ & $6.2 \mathrm{a}$ \\
\hline \multirow[t]{2}{*}{ Dominicana } & $\begin{array}{l}\text { Raw } \\
\text { Boiled }\end{array}$ & $\begin{array}{l}0.2 \mathrm{~d} \\
0.3 \mathrm{c}\end{array}$ & $\begin{array}{l}0.1 \mathrm{f} \\
0.1 \mathrm{f}\end{array}$ & $\begin{array}{l}2.4 \mathrm{~b} \\
0.9 \mathrm{e}\end{array}$ & $\begin{array}{l}0.2 \mathrm{f} \\
9.0 \mathrm{~cd}\end{array}$ & $\begin{array}{l}2.9 \mathrm{~h} \\
4.5 \mathrm{def}\end{array}$ \\
\hline & Microwaved & $0.3 \mathrm{c}$ & $0.1 \mathrm{f}$ & $1.7 \mathrm{c}$ & $9.7 \mathrm{bc}$ & $5.4 \mathrm{bc}$ \\
\hline \multirow[t]{2}{*}{ Mina } & $\begin{array}{l}\text { Raw } \\
\text { Boiled }\end{array}$ & $\begin{array}{l}0.4 \mathrm{~b} \\
0.3 \mathrm{c}\end{array}$ & $0.5 \mathrm{~b}$ & $\begin{array}{l}2.4 \mathrm{~b} \\
0.3 \mathrm{f}\end{array}$ & $0.3 \mathrm{f}$ & $\begin{array}{l}3.8 \mathrm{~g} \\
3.2 \mathrm{~h}\end{array}$ \\
\hline & Microwaved & $0.4 \mathrm{~b}$ & $0.3 \mathrm{~d}$ & $0.7 \mathrm{e}$ & $8.2 \mathrm{~d}$ & $4.3 \mathrm{efg}$ \\
\hline \multirow[t]{2}{*}{ Viola } & Raw & $0.2 \mathrm{~d}$ & $0.2 \mathrm{e}$ & $2.1 \mathrm{~b}$ & $0.3 f$ & $2.8 \mathrm{~h}$ \\
\hline & $\begin{array}{l}\text { Bolled } \\
\text { Microwaved }\end{array}$ & $\begin{array}{l}.3 \mathrm{c} \\
0.3 \mathrm{c}\end{array}$ & $\begin{array}{l}0.1 \mathrm{I} \\
0.1 \mathrm{f}\end{array}$ & $\begin{array}{l}0.6 \mathrm{eI} \\
1.4 \mathrm{~cd}\end{array}$ & $\begin{array}{l}8.6 \mathrm{~d} \\
9.3 \mathrm{bc}\end{array}$ & $\begin{array}{l}4.0 \mathrm{Ig} \\
5.1 \mathrm{bcd}\end{array}$ \\
\hline
\end{tabular}

${ }^{1}$ Mina' did not produce enough tuberous roots when planted in the hot season.

${ }^{2}$ Within columns, means followed by the same letter are not significantly different at $P<0.05$.

of glucose and fructose, a relatively high concentration of sucrose in raw flesh has been reported both for orange-fleshed and white-fleshed cultivars of sweet potato (La Bonte et al., 2000; Picha, 1986). 'Miguela' and 'Dominicana' are considered the sweetest-to-taste cultivars among those evaluated in this study. For these cultivars the percentage of sucrose in raw flesh had a range from 2.0 to 5.1 , whereas concentration of glucose and fructose was less than $1.9 \%$ (Table 1). In the hot season, concentration of sucrose for 'Miguela' and for 'Viola' was significantly reduced by boiling when compared to that in the raw processing treatment (Table 1). In the mild season, concentration of sucrose for all individual cultivars was reduced by both boiling and by baking (Table 
1). In this study, microwaved samples had significantly more sucrose concentration than boiled samples (Table 1). The reduced amount of sucrose concentration in boiled samples as compared to that in microwaved samples has been explained as the diffusion of sugar from the flesh into the water during the boiling process (Martin and Deshpande, 1985).

Maltose is usually in negligible amounts or not detected in raw sweet potato flesh (Lewthwaite et al., 1997; Takahata et al., 1992; Picha, 1985). In this study, we found presence of maltose in flesh subjected to the raw processing treatment (Table 1). This result appeared to be associated with the heating of the flesh sample while drying it to prepare the flour for the extraction of sugars. As expected, maltose concentration in boiled and microwaved roots was significantly higher than that in the corresponding raw roots (Table 1). This result confirms previous research, which indicates that maltose is the main sugar in sweet potato flesh once it is subjected to heat (Hernández-Carrión et al., 2010; Lewthwaite et al., 1997; Picha, 1986; Picha, 1985). In this study, concentrations of maltose among boiled and microwaved samples ranged from $7.1 \%$ to $11.9 \%$ of dry weight. Although methodology among studies varied, percentage values of maltose obtained in this study were lower than those previously reported for 'Miguela', 'Mina' and 'Dominicana', values which ranged from $11.5 \%$ to $18.9 \%$ (Hernández-Carrión et al., 2010).

Concentrations of glucose and fructose were generally less than $1 \%$ for all cultivars and processing treatment combinations, with the exception of their concentration in the raw flesh of 'Miguela' when planted in the hot season (Table 1). As for a preliminary study conducted by Hernández-Carrión et al. (2010), there was not a clear indication regarding the effects of boiling and microwaving on glucose and fructose concentrations. Lewthwaite et al. (1997) reported that cooking causes small changes in glucose and fructose concentrations when compared to those in the raw flesh.

Sucrose equivalents: Results of the present study further pointed out that for this group of cultivars the value of sucrose equivalents is not useful as an indirect measurement of sweetness-to-taste. Hernández-Carrión et al. (2010) reached the latter conclusion with results of a preliminary study with the same cultivars. In this study, for example, raw flesh of 'Miguela' had a sucrose index significantly higher than that of boiled or microwaved flesh (Table 1) although it is well known that raw flesh is not as sweet-to-taste as the flesh is when sweet potato is boiled or microwaved. Across cultivars, sucrose equivalents for raw samples were between 2.5 to 10.0, whereas in boiled and microwaved samples sucrose equivalents ranged from 3.2 to 6.9 (Table 1 ). 
Alcohol insoluble solids: In this study, as expected, AIS for raw roots was significantly higher than that for both the boiled and microwaved roots (Table 2). A reduction in AIS value associated with flesh heating is a trend previously observed for cultivars varying in sweetness (Babu, 1994). In this study, there were no differences in AIS between the boiled and microwaved roots (Table 2). Differences in AIS between raw and heat-processed samples implied that the starch within the flesh was hydrolyzed into sugars during the heating process. The AIS for raw roots were $88 \%$ and $91 \%$, and decreased to $77 \%$ and less after boiling and microwaving (Table 2). When cultivars were compared among themselves for AIS, the AIS of 'Miguela' (78\%) were significantly less than those of the other cultivars (Table 3). This result suggests that for 'Miguela' more starch was converted into sugar than in the other cultivars.

TABLE 2. Percentage of alcohol insoluble solids in sweet potato flesh planted in two seasons and subjected to three processing treatments ${ }^{1}$.

Alcohol insoluble solids

\begin{tabular}{lcc} 
Planting season & Type of processing & $88 \mathrm{a}^{2}$ \\
Hot & Raw & $77 \mathrm{~b}$ \\
& Boiled & $76 \mathrm{~b}$ \\
Mild & Microwaved & $91 \mathrm{a}$ \\
& Raw & $75 \mathrm{~b}$ \\
& Boiled & $75 \mathrm{~b}$ \\
\hline
\end{tabular}

${ }^{1}$ Cultivar by processing treatment interaction was not significant for AIS.

${ }^{2}$ Within columns, means followed by the same letter are not significantly different at $\mathrm{P}<0.05$.

TABLE 3. Percentage of alcohol insoluble solids in sweet potato cultivars planted in two seasons and subjected to three processing treatments ${ }^{I}$.

\begin{tabular}{llc}
\hline & & Alcohol insoluble solids \\
Planting season & Cultivar & $78 \mathrm{~b}^{3}$ \\
\hline Hot $^{2}$ & Miguela & $81 \mathrm{a}$ \\
& Dominicana & $82 \mathrm{a}$ \\
Mild & Viola & $78 \mathrm{~b}$ \\
& Miguela & $81 \mathrm{a}$ \\
& Mina & $82 \mathrm{a}$ \\
& Dominicana & $82 \mathrm{a}$ \\
\hline
\end{tabular}

${ }^{1}$ Cultivar by processing treatment interaction was not significant for AIS.

${ }^{2}$ Mina' did not produce enough tuberous roots when planted in the hot season.

${ }^{3}$ Within columns, means followed by the same letter are not significantly different at $\mathrm{P}<0.05$. 
Sweetness-to-taste and starchiness are traits of a highly subjective nature, depending on particular preferences of consumers. 'Miguela' should be considered as a standard cultivar for sugar and starch content when evaluating cultivars adaptable to the Puerto Rican market. 'Miguela' is sweet-to-taste (Badillo-Feliciano et al., 1976), and within cultivars in this study, it stands out for its relatively high concentrations of sucrose and fructose, and for its reduced AIS.

\section{LITERATURE CITED}

Aina, A. J., K. O. Falade, J. O. Akingbalal and P. Titus, 2012. Physicochemical properties of Caribbean sweet potato (Ipomoea batatas (L) Lam) starches. Food Bioprocess Technol. 5:576-583. Published Online January 2010, DOI: 10.1007/s11947-0090316-6.

Babu, L., 1994. Changes in carbohydrate fractions of sweetpotato tubers on processing. Trop. Agric. 71:71-73.

Badillo-Feliciano, J., 1976. Effects of planting season on yield of sweet potato cultivars. J. Agric. Univ. P.R. 60:163-171.

Badillo-Feliciano, J., A. Morales-Muñoz and C. Sierra, 1976. Performance of whitefleshed sweet potato cultivars at two locations in Puerto Rico. J. Agric. Univ. P.R. $60: 1-8$.

Elliott, R. J., 1995. Learning SAS in the computer lab. Duxbury Press. California. 172 pp

Hernández-Carrión, T., C. E. Ortiz, R. Montalvo-Zapata and L. E. Rivera, 2010. Sugars in tropical-type sweet potato varieties of Puerto Rico. J. Agric. Univ. P. R. 94:205209.

Katayama, K., K. Komae, S. Tamiya, K. Khoyama, M. Nakatani and K. Komaki, 2006. Studies on the breeding for improving starch properties in sweet potato. Japan Agricultural Research Quarterly, (JARQ) 40:115-122.

Koehler, P. E. and S. J. Kays, 1991. Sweetpotato flavor: quantitative and qualitative assessment of optimum sweetness. J. Food Qual. 14:241-249.

La Bonte, D. R., D. H. Picha and H. A. Johnson, 2000. Carbohydrate-related changes in sweet potato storage roots during development. J. Am. Soc. Hortic. Sci. 125:200204.

Lewthwaite, S. L., K. H. Sutton and C. M. Triggs, 1997. Free sugar composition of sweetpotato cultivars after storage. New Zealand J. Crop Hort. Sci. 25:33-41.

Littell, R. C., G. A. Milliken, W. W. Stroup and R. D. Wolfinger, 1996. SAS system for mixed models. SAS Institute Inc. Cary, North Carolina. USA.

Martin, F. W. and S. N. Deshpande, 1985. Sugar and starches in non-sweet sweet potato compared to those of conventional cultivars. J. Agric. Univ. P.R. 69:401-406.

Mcharo, M. and D. La Bonte, 2007. Genotypic variation among sweet potato clones for ß-carotene and sugar content. Proc. 13th ISTRC Symposium, pp. 746-754.

Noda, T., Y. Takahata, T. Sato, T. Kumagai and O. Yamakawa, 1998. Starch properties and cell-wall material contents in sweet potatoes as affected by flesh color, cultivation method and year. J. Appl. Glycosci. 45:1-9.

Picha, D. H., 1985. HPLC determination of sugars in raw and baked sweet potatoes. $J$. Food Sci. 50:1189-1190, 1210.

Picha, D. H., 1986. Sugar content of baked sweet potatoes from different cultivars and lengths of storage. J. Food Sci. 51: 845-846, 848. 
Takahata, Y., T. Noda and T. Nagata, 1992. Varietal diversity of free sugar composition in storage root of sweet potato. Jpn. J. Breed. 42:515-521.

University of Puerto Rico, Agricultural Experiment Station, 1997. Conjunto tecnológico para la producción de raíces y tubérculos. Publicación 101(revised). University of Puerto Rico, Mayagüez Campus. 34 pp.

Walter Jr., W. M., A. E. Purcell and A. M. Nelson, 1975. Effects of amylolytic enzymes on "moistness" and carbohydrate changes of baked sweet potato cultivars. J. Food Sci. 40:793-796.

Walter Jr., W. M., W. W. Collins, V. D. Troung and T. I. Fine, 1997. Physical, compositional and sensory properties of french fry-type products from five sweet potato selections. J. Agric. Food Chem. 45:383-388. 
